\title{
Different Types of Properties of Cane Juice Centrifugation
}

\author{
Monika Soni \\ President, Auricle Global Society of Education and Research \\ India \\ 12.monika@gmail.com
}

\section{Abstract:}

The affirmation of rotator for the specific kind of suspension needs some key data. The particles, which are open in different sizes, their task in the medium, outstanding thickness, thickness, etc are the major norms. It includes a central screw type transport which clears the saved solids. The speed keeps up could be around $8000 \mathrm{rpm}$ in the level of 70-75\% mud moisture. In this paper we are examining centrifugation of stick juice in the sugar business.

Keywords: ICUMSA, Centrifugation, Cane juice, viscosity etc.

\section{INTRODUCTION}

Centrifugation is one of the main unit assignments in the sugar business. The segment of suspended particles and characteristic salts at a basic stage and at an encompassing temperature (at the infection stage) profitably influences clarification. Something different, at a higher temperature the deterioration of suspended particles will undoubtedly occur. In the last case, the separation will be progressively irksome and will extend the scale declaration in a glow exchanger similarly as addition the consistency. This decline of mud will in like manner decrease the volume of mud commonly procured from the clarifier, which is around $25 \%$ on stick. As needs be, the stack on the vacuum turning channel will be decreased by $5-7 \%$. The filterability of centrifuged mud/juice may speak to an issue without suspended particles. the physical appearance of the compensated juice is breathtaking with a trace of turbidity containing a humble amount of floating bagacillo. An in a general sense equivalent to greenish clue was moreover uncovered by Hionig, while the concealing estimation shows an extraordinary improvement in view of centrifugation. In Indian conditions, the earth cure plays a critical factor in the examination of the sugar balance. As opposed to the standard methodology, if the centrifuged juice is genuinely checked, the sugar balance report could be made progressively careful. This is an additional piece of elbowroom of the treatment. 


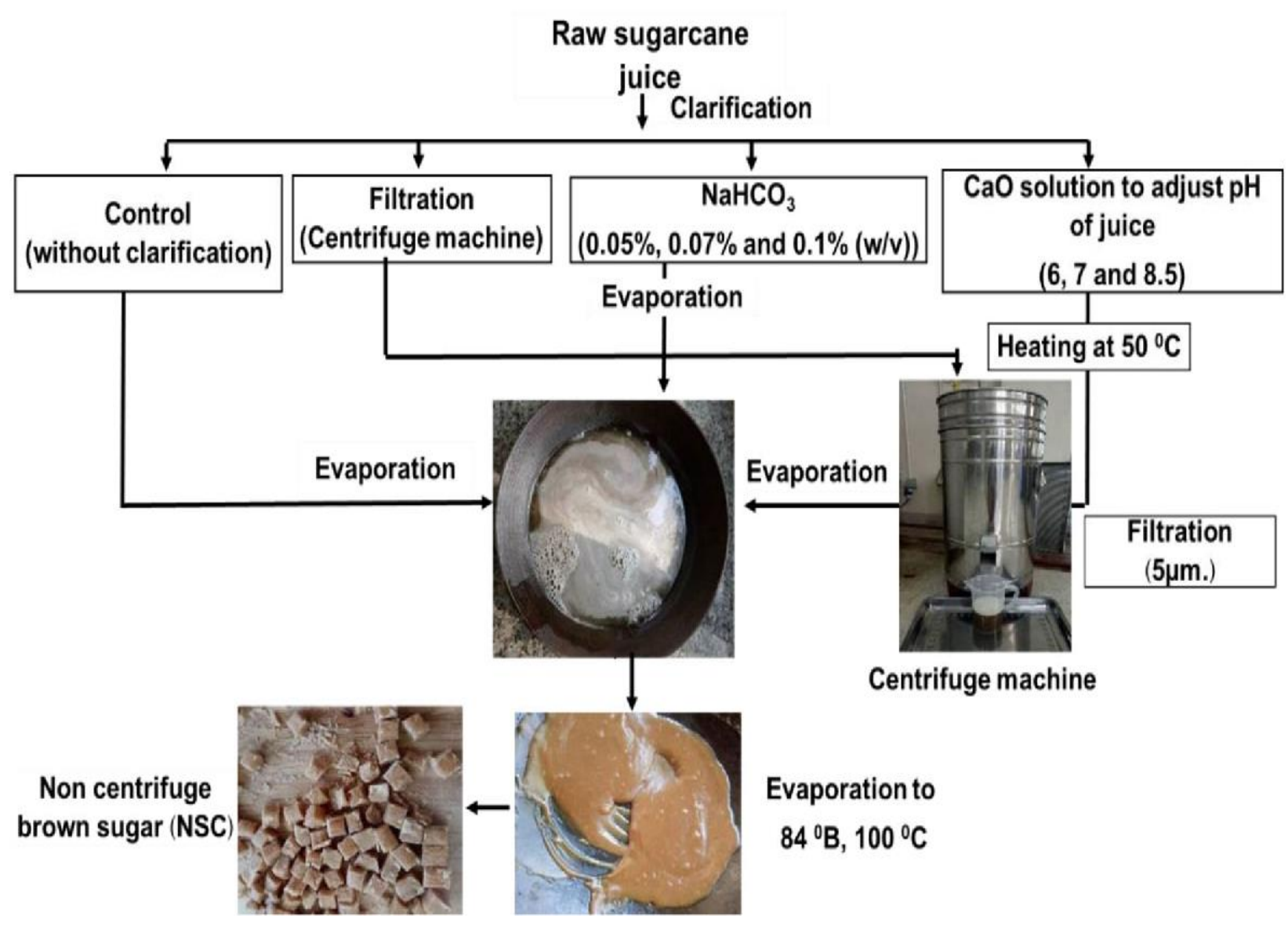

Fig 1: cane juice centrifugation

\section{MATERIALS AND METHODOLOGY}

Cane juice samples were subjected to centrifugation using a Remi R-8 C batch-type laboratory model. This was operated at $6000 \mathrm{rpm}$, attaining $2000 \mathrm{~g}$ at the bottle tip. For every run it was set for 5 minutes. Optimization of the centrifuge operation is a function of design and so was not carried out. Only the various effective parameters due to centrifugation of cane juice have been observed in the present study. Purity measurement of cane juice was done using a Sucromat in a conventional way. A Brookfield RVT viscometer was used to measure the apparent viscosity difference at $50 \mathrm{rpm}$ using spindle No.1 The ICUMSA colour measurement was done using TEA-buffer and membrane filter as described elsewhere. The colour measurements were carried out on an ELICO spectrophotometer. 


\section{DATA ANALYSIS AND INTERPRETATION}

TABLE I

\begin{tabular}{|l|c|c|c|c|c|}
\hline MEDIUM & $\begin{array}{l}\text { WET } \\
\text { MUD \% }\end{array}$ & $\begin{array}{l}\text { MOIS } \\
\text { TURE }\end{array}$ & $\begin{array}{l}\text { CHEMICAL LOAD } \\
\text { MILK OF LIME }\end{array}$ & $\begin{array}{l}\text { ASH \% ON } \\
\text { CANE }\end{array}$ & $\begin{array}{l}\text { ASH \% } \\
\text { ON }\end{array}$ \\
\hline & W/ & & SO & JUI & MU \\
& W & & 2 & CE & D \\
\hline CANE & - & - & $11.8 \mathrm{C}$ & & - \\
JUICE & & & C X & & 11. \\
TREATED & 5. & 75.7 & $12.5 \mathrm{C}$ & 2 & 5 \\
JUICE & 2 & & C X & & \\
& & & & & \\
\hline
\end{tabular}

TABLE II

\begin{tabular}{|l|l|l|l|}
\hline MEDIUM & $\begin{array}{l}\text { VISCOSITY } \\
\text { CPS }\end{array}$ & $\begin{array}{l}\text { CLARI } \\
\text { TY }\end{array}$ & ICUMSA UNITS \\
\hline CANE JUICE & 1.25 & 42.8 & 4220.00 \\
\hline TREATED JUICE & 1.18 & 13.5 & 3294.00 \\
\hline CLEAR JUICE & 1.02 & 11.8 & 2815.00 \\
\hline
\end{tabular}



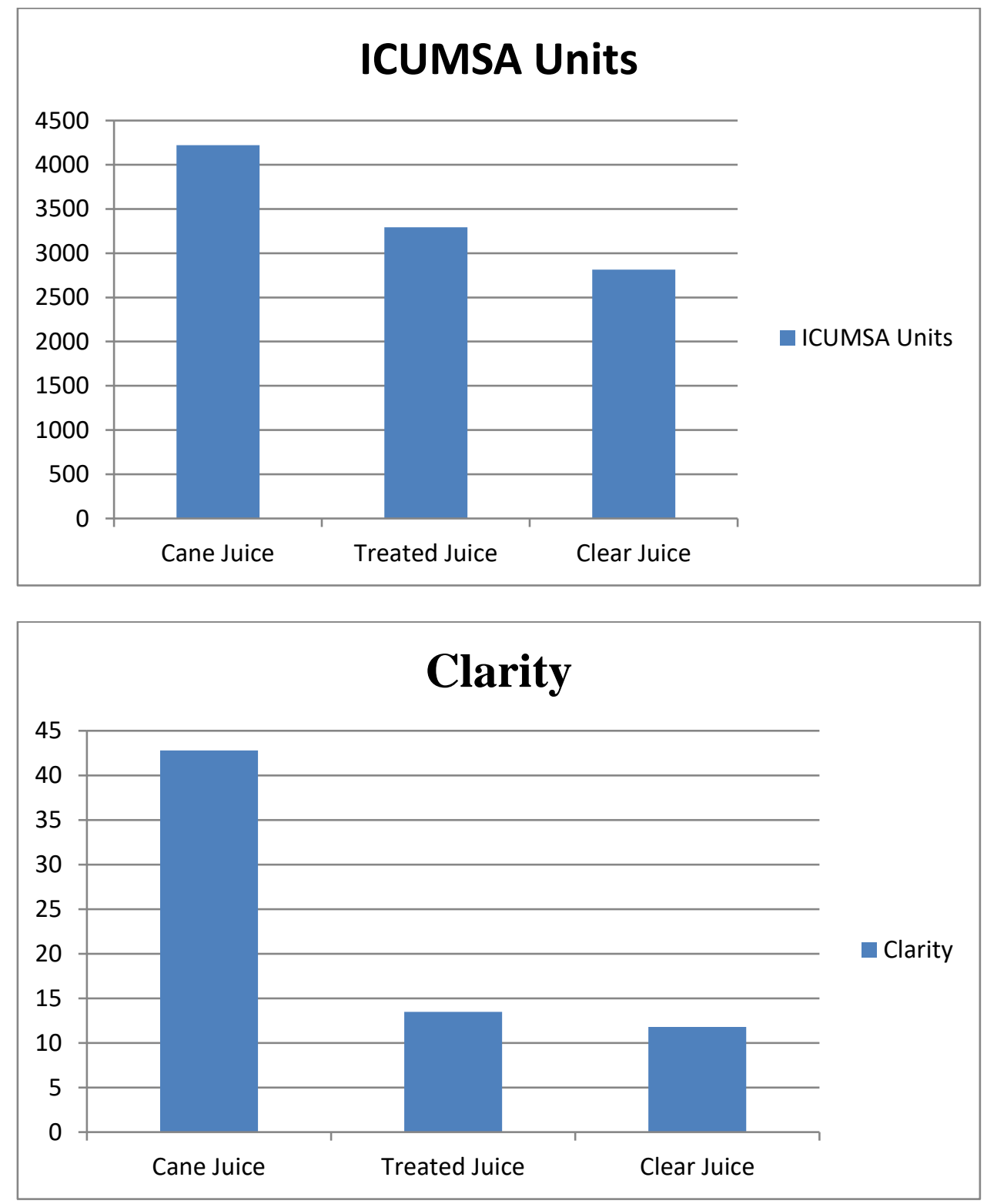

\section{CONCLUSION}

The study involves the centrifugation of cane juice. The juice is subjected to centrifugation directly after milling of the cane. This treatment has been thought of particularly to clarify juices by removing the suspended particles, viz. silica, organic salts, etc. along with mud. In this paper the design pattern of the centrifuge has been shown. The effective factors such as removal of suspended particles, clarity and ICUMSA colour of the centrifuged juice has shown by the table and graph. 


\section{REFERENCES}

[1] Premalatha M (2008) Efficient cogeneration scheme for sugar industry. Journal of Scientific \& Industrial Research 67:239-242

[2] Birru (2007) Investigation of the potential of sugar cane industries (MSc thesis)

[3] Marianela Cordovés Herrera(1999). "CaneSugar and The environment-Cuba conference”. Available at http://www.fao.org/docrep/005/X4988E/x4988e01.htm. Accessed March 2012

[4] Ingaramo A, Heluane H, Colombo M, Cesca M (2009) Water and wastewater eco-efficiency indicators for the sugar cane industry.Journal of Cleaner Production $17: 487-495$

[5] Kamate CS and Gangavati BP (2009) Cogeneration in Sugar Industries: Technology Options and Performance Parameters-A Review, Cogeneration \& Distributed Generation Journal, 24:4, 6-33, DOI: $10.1080 / 15453660909595148$

[6] Raghu RJ, Banerjee R(2003)Energy and cogeneration targeting for a sugar factory. Applied Thermal Engineering 23:1567-1575

[7] Ensinas VA, Lozano MA, Serra LM (2007) Analysis of process steam demand reduction and electricity generation in sugar and ethanol production from sugarcane. Energy conversion \& Management 48:2978-2987

[8] Lavarack BP, Hodgson JJ, Broadfoot R, Vigh,S and Venning J (2004) Improving the energy efficiency of sugar factories: Case study for pioneer mill Proc. Aust. Soc. Sugar Cane Technology: 26

[9] ABB (2010) ACS 1000 variable speed drives increase energy efficiency at sugar plant-case study. Available http://www05.abb.com/global/scot/scot216.nsf/veritydisplay/46ae6cf38fa1228bc12577e40056e21d/\$ file/CS_Sugar\%20RevB_lowres.pdf

[10] Dias SOM, Modesto M, Ensinas VA, Nebra AS, Filho MR, Rossell VEC (2011) Improving bioethanol production from sugarcane: evaluation of distillation, thermal integration and cogeneration systems. Energy 36:6, 3691-3703

[11] Solomon S (2011) The Indian Sugar Industry: An Overview. Sugar Technology 13(4):255-265

[12] Keerthipala RA (2007) Sugar Industry of Sri Lanka: Major Issues and Future Directions for Development. Sugar Technology :9(1) 1-10

[13] Ethiopian sugar corporation. Available at http://www.etsugar.gov.et/

[14] Alonso-Pippo W, Luengo AC, Koehlinger J, Garzone P, Cornacchia G (2008) Sugarcane energy useThe Cuban case. Energy Policy 36 : 2163-2181

[15] Edward D (1981)Standard Fabrication Practices for Cane Sugar Mills. Amsterdam: Elsevier Scientific Pub. Co. ; New York: Elsevier Scientific Pub. Co. ; New York: Elsevier Scientific Pub. Co. ISBN0-444-41958-6;ISBN1-322-26407-4;ISBN1-4832-8967-2

[16] Costa, A. F. S.; Nascimento, V. R.; Amorim, J. D. P.; Gomes, E. A. S.; Araujo, L. M.; Sarubbo, L. A. Residue from the production of sugar cane: an alternative nutrient used in biocellulose production by Gluconacetobacter hansenii. Chemical Engineering Transactions, v. 64, p. 7-12, 2018. DOI: 10.3303/CET1864002

[17] Hamerski, F. Study of variables in the process of carbonation of the broth of sugar cane. p. 148. Dissertation. Graduate degree in food technology. Federal University the Paraná, Curitiba, 2009.

[18] Alemu Aderu; 2009; "Energy assessment, energy utilization \& generation efficiency (a case study in Finchaa sugar factory)",MSc thesis 